\title{
Assessment on Geography Field study at Universities in Indonesia
}

\section{Aris Munandar ${ }^{a, 1}$, Enok Maryani ${ }^{b}$, Dede Rohmat $^{\mathrm{b}}$, Mamat Ruhimat ${ }^{\mathrm{b}}$}

${ }^{a}$ Department of Geography Education, Faculty of Social Science, Universitas Negeri Jakarta, Jakarta, Indonesia

a Department of Geography Education, Faculty of PIPS, Universitas Pendidikan Indonesia, Bandung, Indonesia

1 amunandar@unj.ac.id

\begin{tabular}{lll}
\hline Informasi artikel & A B S T R A K \\
\hline Sejarah artikel & Dalam Program Studi Geografi, studi lapangan adalah ciri khas \\
Diterima & $:$ & pembelajaran luar ruang geografi. Kegiatan serupa dari studi lapangan \\
Revisi & $:$ & adalah penelitian lapangan, kunjungan lapangan, tamasya, dan lainnya. \\
Dipublikasikan $:$ & Implementasi studi lapangan pada universitas pencetak guru geografi \\
\hline Kata kunci: & memiliki kesamaan dalam penamaannya, definisi, tujuan, bahan studi, \\
Kuliah lapangan & durasi kegiatan, lokasi studi lapangan, dan pemrosesan data. Perbedaan \\
Penilaian & implementasi studi lapangan terletak pada rasio pengawas untuk siswa, \\
Geografi & pendanaan, produk hasil, dan sistem penilaian. Universitas yang \\
& melakukan studi lapangan harus meninjau kurikulum dalam \\
& implementasinya sehingga kredit, produk yang dinilai dan prosesnya \\
& memiliki kesamaan baik dalam kredit dan pengawas yang menilai.
\end{tabular}

Keywords:

Field study

Assessment

Geography

\begin{abstract}
A B S T R A C T
In Geography Study Program, fieldstudy is the hallmark of geography outdoor learning. The similar activities of fieldstudy are fieldwork, fieldtrip, outing, excursion, cooks tours and others. The implementation of fieldstudy in the universities of teacher training has the similarity in its naming, its definition, its purpose, material of the study, the duration of the activity, the location of the fieldstudy, and data processing. The difference of the fieldstudy implementation lies on the ratio of supervisor to students, funding, outcome product and assessment. Universities that conduct the fieldstudy should review the curriculum in its implementation so that the credit, the assessed product and process have the similarity both in the credit and the supervisors who assess.
\end{abstract}

\section{Introduction}

Concerning with fieldstudy, fieldwork (work in the field) is considered equal to fieldstudy. In geography the use of fieldwork often overlaps with fieldtrip, picnic, outing, excecursion (Lewis, 1968). Therefore, the term fieldwork is still debated, in this case, fieldstudy is defined as fieldwork that may include field teaching, field trips, field reseach or field camps (Dando \& Wiedel 1971). This term (fieldwork) has five types: Short field excursion, Cook's Tour, Residential course, Study tour and Project work. Fieldtrip itself is a termimology referring to Intractional trip, school ecercusion, school journey (Krepel \& Duvall, 1981, Marc Behrendt, Theresa Franklin 2014). The UK Quality Assurance Agency (QAA) defines fieldwork as an "active engagement with the external world' (QAA, 2002). Fieldwork can be defined as a learning activity that brings a direct experience in the real field, not like in the classroom setting (Neil lobo 2007, Lonergan and Andresen, 1988).

Geography without fieldwork is like science without experiment (Colin Marsh, 2008, p.311). Field is a geography laboratory where the landscape, site, people and their characterictics can be obtained directly and students can learn to collect the data and practice in the real environment (Rod Berges, 2000, p.120). The essence of fieldwork is the process of data collection and analysis about feature or phenomena on the spot (Stephen Pui-ming Yeuing, 2009, p. 51). Historically, fieldwork is a direct observation in the field or a teaching and 
learning process which orientates on: 1) the study of geography process compared to observation and description; 2) a research and a problem solving approach (Ian Fuller, 2006, ed Bradbeer., 1996).

Daniela Tilburry (1997, p.189) grouped geography fieldwork into three categories, that are outdor studies, outdor pursuits, personal and social development. Fieldwork can improve students' comprehension on theories specifically, transfer skills, encourage more active learning and relate theories to the real world (Max Hope, 2009, p.169). Fieldwork gives an opportunity to learn the real thing not the imitation in the class that improving the students'comprehension on the geography concept and appearance and developing their specific skills (HMI, 1992). When fieldstudy is conducted, there is an effective relationship between the emotion and the intensive learning value among learners'responses (Higgitt, 1996; Fuller et al., 2006; Boyle et al., 2007). Fieldwork is a structured experience of the students who study outside the classroom with the objects in the form of buildings, geology sites, museums or any places where students study. The trip can be done in a few hours/days/staying some weeks in order to be able to assess the students' learning outcomes (Rod Berges, 2000. Jenkin, 1977).

The implementation of fieldstudy needs a careful consideration in its operational techniques, determining location, theme and curriculum, preparing the implementation, staff supports, developing skills that will be done, analyzing the field data and the activity after fieldstudy. It also needs a careful estimation from the preparation stage, implementation and after fieldstudy (Ian Fuller, 2006, Kent, 1997).

\section{Brief History}

Based on the result of the study of Sri Mulyantari (2005), she concluded that fieldstudy in the form of Kuliah Kerja Lapangan I at Geography Department, Semarang State University can be as one of the contextual learnings, but the inquiry (the finding component) and the authentic assessment (the real assessing component) still need to improve. Fieldstudy requires assessment procedures and conducive situation among staffs, participants, curriculum, institutions and others concerning with the fieldstudy (Ian Fuller, 2006, Gold et al, 1991). The use of a written test in the fieldwork is not appropriate (David Lambert Michael J Reiss, 2014, p. 16).

The result of tracer study on fieldstudy in some countries in Southeast Asia in the form of the fieldwork activity taken from Rod Gerber (2000, p. 104) shows any variation in its implementation. The implementation of fieldstudy in some universities at Southeast Asia is various from the type, time/duration, student group, site location, final product and assessment. The various type of field activity such as fieldtrip, fieldwork, intensif residential also makes the other various element/variables.

Based on the table above, the fieldstudy conducted in the universities of teacher training in Indonesia (State University of Jakarta-UNJ, Indonesia Education University-UPI, State University of Yogyakarta-UNY and State University of Semarang-UNES) would be identified and analyzed. This article aims at seeing the implementation of fieldstudy at four universities that have the same characteristic, the universities that graduate teachers located in Java Island, Indonesia. These universities should have the similarity in implementing fieldstudy because of their same result of learning outcomes. Process, product and assessment generated in the fieldstudy activity should have the same characteristics.

\section{Contex And Review Literature Fieldstudy at universities}

According to IAAM $(2013,214)$ Fieldwork has been done since the sixth level. The purpose of fieldwork in Geography describes a pattern and a relation in the land span. Fieldwork in Geography at University of New Zealand is less 
prominent because it is intregated and inserted in teaching and learning compared to the implementation of fieldwork separately, such as an active learning that develops the affective domain dan the value improvement in fieldwork (Ian Fuller, 2006, Kern \& Carpenter, 1984, 1986).

Geography Department at National Universty of Singapura obliges the first semester students to take fieldwork focusing on physical and human geography. Students should make a profile of the result in measuring temperature and humidity related to the site variation and, at the same time, also make a report of spatial characteristics. This fieldwork is generally conducted by bus with the 50-250 participants, using any tools such as theodolite, compass, etc. The material of physical geography are rock formations, geomorphology, biogeography, and hydrology (Rod Gerber: 2000).

The result of tracer study on the implementation of fieldstudy at four universities are taken from the available documents. Some documents complete each other using the set indicators. The similarities and the differences are made to conclude toward the tendencies of any aspects in the implementation of fieldstudy. The table of the similarities and the differences of fieldstudy is as at table 1.

The four universities have the similarities and the differences in the fieldstudy activity. The similarity is in naming, that is there is a word 'field' at every outdoor activity. To differentatiate the implementation that is conducted three times, it is used the Roman alphabet I, II, III or showing material of the study: physic, human or intergrated study between physic and human. The definition of fieldstudy tends to be the same, the outdoor activity. The purpose is adjusted to the stages/levels of fieldstudy. The similarities were also found in material of the study, duration, location setting and data processing.

The differences in the implementation of fieldstudy are the ratio of the supervisor to students which is various between 1:15 and 1:20. This ratio is still acceptable according to the result of study from Daniel Tilbury (2001). The bigger ratio than $1: 20$ does not enable the lecturer to supervise in the field. The big ratio makes the lecturers unable to manage, control the activity in the field. The fieldstudy activity taking the group out of the class also needs the big funding.The funding for fieldstudy at the four universities are various. Two universities get the funding from the allocation of single tuition fee (UKT) per semester that is paid early in order not to take more money for three implementations of fieldstudy. Meanwhile, one university takes selffinancing for the fieldstudy although students have paid UKT because it does not cover the activity of fieldstudy; and the other one funds the fieldstudy by combining UKT and self-financing.

\section{Method}

This study used a descriptive method to see existing condition/to identify the implementation of fieldstudy exsisting in the four universities. Source of the data in this study are the research reports, documents of course outlines (Satuan Acara Perkuliahan-SAP), Academic Guidelines (Buku Pedoman Akdemik-BPA), System Operating Procedures (SOP) and other documents. The documents are analyzed based on the indicators: naming, the quantity, the objective, semester credits (SKS), the mechanism of implementation, material of the study, duration, site location, the ratio of the supervisor to students, funding, generated product/outcome and assessment. Analysis was conducted to find the similarities and the differences at the existing indicators, then concluded based on the tendencies. The next analysis was cross-tabulating on the implementation of fieldstudy concerning with its mechanism in the form of process and product of the fieldstudy and its assessment that are conducted. 
Table 1. The similarities and the differences of fieldstudy at four universities

\begin{tabular}{|c|c|c|c|c|c|c|}
\hline No & Aspects & UNY & UPI & UNJ & UNES & CONCLUSION \\
\hline 1 & Naming & $\begin{array}{l}\text { PKL Dasar (Basic Fieldstudy) } \\
P K L \text { Geografi ekonomi dan } \\
\text { social (Fieldstudy in } \\
\text { economic and social } \\
\text { geography) } \\
\text { PKL geografi terpadu } \\
\text { (Integrated Fieldstudy in } \\
\text { Geography) }\end{array}$ & $\begin{array}{l}\text { PKL I(Fieldstudy I) } \\
\text { PKL II (Fieldstudy II) } \\
\text { PKL III (Fieldstudy III) }\end{array}$ & $\begin{array}{l}\text { PKL fisik (Physical Fieldstudy) } \\
P K L \quad \text { Sosial Ekonomi dan } \\
\text { Pemetaan (Fieldstudy in social- } \\
\text { economy and mapping) } \\
\text { PKL terpadu (Integrated } \\
\text { Fieldstudy) }\end{array}$ & $\begin{array}{l}\text { KKLI(Fieldstudy I) } \\
K K L I I \text { (Fieldstudy II) } \\
K K L I I I \text { (Fieldstudy III) }\end{array}$ & $\begin{array}{l}\text { Tend to be the same } \\
\text { There is a phrase 'field study' in } \\
\text { naming the activity }\end{array}$ \\
\hline 2 & Definition & Outdoorstudy Program & Outdoor learning & Outdoor learning & $\begin{array}{l}\text { Supporting courses in } \\
\text { the classroom }\end{array}$ & $\begin{array}{l}\text { Tend to be the same } \\
\text { There is an outdoor activity or } \\
\text { outdoor learning }\end{array}$ \\
\hline 3 & Quantity & 3 times & 3 times & 3 times & 3 times & Same \\
\hline 4 & Purpose & $\begin{array}{l}\text { Adjusted to the level of } \\
\text { fieldstudy }\end{array}$ & $\begin{array}{l}\text { Having the analyzing skill } \\
\text { and ability to utilize } \\
\text { environment as learning } \\
\text { sources }\end{array}$ & $\begin{array}{l}\text { Adjusted to the level of } \\
\text { fieldstudy }\end{array}$ & $\begin{array}{l}\text { Applying concepts and } \\
\text { theories taken in the } \\
\text { classroom }\end{array}$ & Tend to be the same \\
\hline 5 & $\begin{array}{l}\text { Course Credit } \\
\text { (System of } \\
\text { Semester } \\
\text { Credit/SKS) }\end{array}$ & $1+1+1=3$ & $0,5+0,5+1=2$ & $1+1+2=4$ & ------------- & $\begin{array}{l}\text { Different } \\
\text { The smallest credit is UPI } \\
\text { In UNES the data is not found }\end{array}$ \\
\hline 6 & $\begin{array}{l}\text { Activity } \\
\text { mechanism }\end{array}$ & $\begin{array}{l}\text { pre-activity-activity- } \\
\text { post-activity }\end{array}$ & $\begin{array}{l}\text { pre-activity-activity- } \\
\text { post-activity }\end{array}$ & $\begin{array}{l}\text { pre-activity-activity- } \\
\text { post-activity }\end{array}$ & $\begin{array}{l}\text { preparation- } \\
\text { implementation- } \\
\text { final stage } \\
\end{array}$ & Same \\
\hline 7 & $\begin{array}{l}\text { Material of } \\
\text { the study }\end{array}$ & $\begin{array}{l}\text { Object of the study: } \\
\text { Physical, human and } \\
\text { integrated }\end{array}$ & Process of the study & $\begin{array}{l}\text { Object of the study: } \\
\text { Physical, human } \\
\text { integrated }\end{array}$ & $\begin{array}{l}\text { Object of the study: } \\
\text { Physical, human and } \\
\text { integrated }\end{array}$ & Tend to be the same \\
\hline
\end{tabular}




\begin{tabular}{|c|c|c|c|c|c|c|}
\hline 8 & Duration & 4-5 days & 4-5 days & 4-5 days & 4-5 days & Same \\
\hline 9 & $\begin{array}{l}\text { Setting } \\
\text { Location }\end{array}$ & $\begin{array}{l}\text { a. The conformity of } \\
\text { location with theme } \\
\text { b. The appearance of } \\
\text { prominent sign } \\
\text { c. Reachable location } \\
\text { d. Safe to visit } \\
\text { e. The cost to visit is } \\
\text { relatively cheap } \\
\text { f. The availability of } \\
\text { initial data of the } \\
\text { location }\end{array}$ & $\begin{array}{l}\text { Location is prepared by the } \\
\text { committee decideb by the } \\
\text { lecturer board }\end{array}$ & $\begin{array}{l}\text { Location is agreed between } \\
\text { the lecturer team and the } \\
\text { committee. }\end{array}$ & $\begin{array}{l}\text { Object is decided } \\
\text { together between the } \\
\text { lecturers and students }\end{array}$ & Tend to be the same \\
\hline 10 & $\begin{array}{l}\text { Ratio of the } \\
\text { supervisor to } \\
\text { students }\end{array}$ & $1: 15$ & $1: 15$ & $1: 20$ & - & Different \\
\hline 11 & Funding & Single tuition (UKT) & Self-financing & $\begin{array}{l}\text { Single tuition (UKT)) and Self- } \\
\text { financing }\end{array}$ & Single tuition (UKT) & Tend to be various \\
\hline 12 & $\begin{array}{l}\text { Product } \\
\text { generated }\end{array}$ & Final report & Paper, article, leaflet, report & Report, standing banner & Report & Various \\
\hline
\end{tabular}




\begin{tabular}{|c|c|c|c|c|c|c|}
\hline 13 & Assessment & $\begin{array}{l}\text { Fieldstudy of social } \\
\text { economic geography } \\
\text { a. Participation in } \\
\text { debriefing session (5\%) } \\
\text { b. Team work (10\%) } \\
\text { c. Participation in the } \\
\text { field (25\%) } \\
\text { d. Making a report 15\%) } \\
\text { e. Final exam (45\%) } \\
\text { Integrated Fieldstudy } \\
\text { a. Activity during the } \\
\text { implementation, both } \\
\text { at the debriefing } \\
\text { session and in the field } \\
\text { including: } \\
\text { participation, } \\
\text { discipline } \\
\text { teamwork, in } \\
\text { participation in } \\
\text { scientific } \\
\text { discussion, } \\
\text { b. Final } \\
\text { Presentation Report } \\
\text { c. Participation at the } \\
\text { debriefing session (5\%) }\end{array}$ & $\begin{array}{l}\text { a. Cognitive, affective and } \\
\text { psychomotor } \\
\text { b. Presence in preparation } \\
\text { minimal } 3 \text { times } \\
\text { c. Presence in the field, } \\
\text { Presence and expose } \\
\text { performance } \\
\text { d. Paper } \\
\text { e. Article } \\
\text { f. Leaflet } \\
\text { g. Report }\end{array}$ & $\begin{array}{l}\text { Fieldstudy of physical } \\
\text { geography } \\
\text { a. Presence in the course and } \\
\text { debriefing sessions = } 10 \\
\% \\
\text { b. Participatory and } \\
\text { participation } \\
=60 \% \\
\text { c. Group report = } 30 \% \\
\text { Fieldstudy of Sosekta and } \\
\text { integrated geography } \\
\text { a. Implementation of fieldstudy } \\
=60 \% \\
\text { b. Presentation of fieldstudy } \\
=10 \% \\
\text { c. Report of fieldstudy = } 30 \%\end{array}$ & 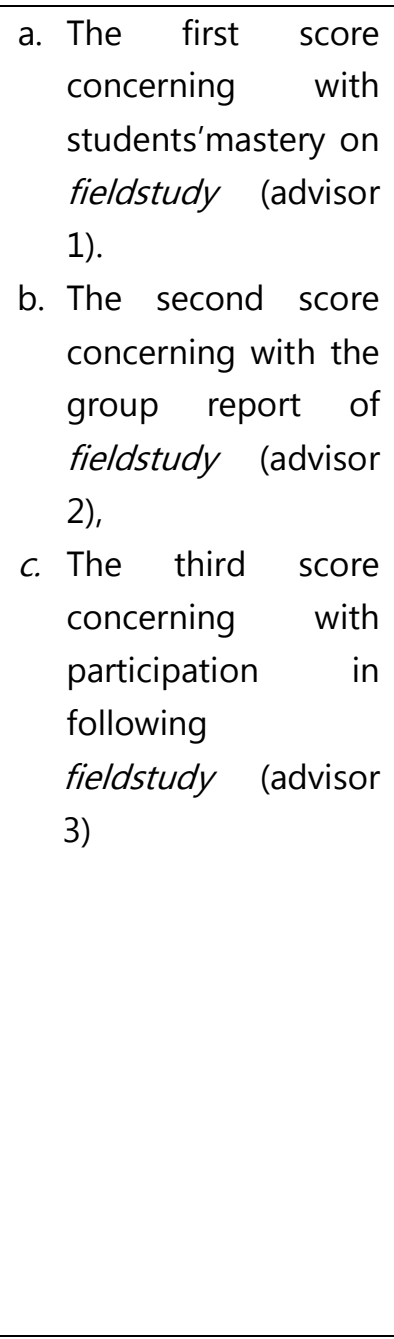 & $\begin{array}{l}\text { Same, the differences lie on the } \\
\text { types of product and process } \\
\text { and their weighting }\end{array}$ \\
\hline 14 & $\begin{array}{l}\text { Data } \\
\text { collecting } \\
\text { process }\end{array}$ & & $\begin{array}{l}\text { Observation, interview, } \\
\text { questionnaire, documentary } \\
\text { study }\end{array}$ & $\begin{array}{lr}\text { Observation, } & \text { interview, } \\
\text { questionnaire, } & \text { documentary } \\
\text { study }\end{array}$ & $\begin{array}{l}\text { Observation, interview, } \\
\text { questionnaire, } \\
\text { documentary study }\end{array}$ & Same \\
\hline
\end{tabular}


Table 2. Assessment of fieldstudy at four universities

\begin{tabular}{|c|c|c|c|c|c|c|}
\hline \multirow[t]{2}{*}{ No } & \multirow[t]{2}{*}{ Mechanism } & \multirow[t]{2}{*}{ Product and Process } & \multicolumn{4}{|c|}{ Weighing } \\
\hline & & & UNY & UPI & UNJ & UNES \\
\hline \multirow[t]{2}{*}{1} & Pre-activity & $\begin{array}{l}\text { Participation in } \\
\text { debriefing session }\end{array}$ & $5 \%$ & $\begin{array}{l}\text { There are } \\
3 \text { times }\end{array}$ & $10 \%$ & $\begin{array}{l}\text { There is, } \\
\text { Assessed by } \\
\text { supervisor } 1\end{array}$ \\
\hline & & Team work & $10 \%$ & - & - & - \\
\hline 2 & Activity & $\begin{array}{l}\text { Participation in the } \\
\text { field }\end{array}$ & $25 \%$ & - & $60 \%$ & $\begin{array}{l}\text { There is, } \\
\text { Assessed by } \\
\text { supervisor } 3\end{array}$ \\
\hline \multirow[t]{8}{*}{3.} & Post-activity & Final Exam & $45 \%$ & - & - & - \\
\hline & & Report & $15 \%$ & $42 \%$ & $30 \%$ & $\begin{array}{l}\text { There is, } \\
\text { Assessed by } \\
\text { supervisor } 2\end{array}$ \\
\hline & & $\begin{array}{l}\text { Presentation of final } \\
\text { report }\end{array}$ & $5 \%$ & $42 \%$ & - & - \\
\hline & & Leaflet & - & There is & - & - \\
\hline & & Article & - & - & - & - \\
\hline & & Paper & - & - & - & - \\
\hline & & & & $16 \%$ & - & - \\
\hline & & Total & 100 & 100 & 100 & - \\
\hline
\end{tabular}

\section{Result}

Assesment of fieldstudy

Based on the table of the similarities and the differences of fieldstudy at four universities, the cross-tabulating concerning with the mechanism, product and assessment is done. The result of tabulating is as in Table 2 .

All of the four universities have the similarities in the mechanism implementation of fieldstudy, fieldstudy is conducted three times. Each of fieldstudy conduct the same mechanism of implementation: pre-fieldstudy, fieldstudy (implementation) and post-fieldstudy. Although the mechanism is same, the product, the process, the weighing and the assessment are different.

The product generated in the fieldstudy can be a report, a leaflet, an article and/or a paper. The four universities oblige students to make a final report of the implementation of fieldstudy. The final report is a group report as one of the activities to prepare and train students in collecting, processing and analyzing field data. The group report trains the participants to write a final report scientifically for their final report at the end of their study. The different products generated are a paper, a leaflet an article (UPI). The product is important for the participants as an effort to publish in any event/exhibition/other scientific activities.

Assessing the attitude on the participation aspect at pre-fieldstudy and at fieldstudy in four universities is considered something important. This stage needs the participation of all participants in planning a fieldstudy, an intensive participation in direct learning in the field (Martin Kent, David D Gilbertson, Chris O Hunt, 1997). Both fieldstudy and fieldwork require the participation of the participants. Fieldwork can be planned carefully in the annual calender system. The careful planning which considers the course schedule can reduce any risks will happen concerning with permitting documents, the participants'safety and health, and others (Daniella Tilbury, 1997, p.199). The participation of the participants in fieldstudy is not only in planning, but also in implementing. 
The difference in assessing lies on the obligatory for students to take a final exam that happen in UNY, while three other universities do not. The difference is also found in weighing the indicators. The percentage given by each university has its own reasons adjusted to the types of tasks/the process. Even in UNES, this university uses the different model of assessment. The three supervisors that at once as the assessors have a different task. The first supervisor assesses the pre-activity, the third supervisor assesses the activity in the field and the second supervisor assesses the post-activity.

\section{Discussion}

Based on the similarities and the differences in implementing fieldstudy, the universities are expected to discuss and analyze the curriculum as the reference in implementing fieldstudy (Kwok Chan Lai and Chi Chung Lam, 2013). In the curriculum, there is a lesson plan/teaching planning. According to Daniella Tilbury (1997, p.195), fieldwork planning begins by seeing Planning of Teaching and Learning Programme (Course Outline) in which there are objective, learning outcome, method, required facilities, time and activities. It needs a curriculum analysis or reconstruction to get the same comprehension of the differences in weighing credit, product and process, types of assessment and the supervisors who assess.

In addition, this analysis is conducted to see the activities in feldstudy. In general, the outdoor activity such as fieldstudy or fieldwork has two activities: observation and participation (Martin Kent, David D Gilbertson, Chris O Hunt, 1997).

Dealing with two general activities above, types of assessment also refer to observation and participation. Based on the analysis result of types of assessment, the writer suggests three assessments: project, performance and portfolio. Portfolio is recommended in the activity of fieldstudy (David Lambert Michael J Reiss, 2014). First, portfolio in the activity of fieldstudy can be a leaflet, a standing banner or an article. Second, performance assessment-assessing participation between partcipants and their supervisor in making preparation, doing a project, encountering a difficulty in the field such as health, etc. Therofore, alternative assessment (Lonergan \& Andersen, 1988; Kneale, 1996: Mc Ewen \& Harris, 1996) such as oral presentation is also suggested as a type of assessment. Assessing oral presentation uses performance assessment. Third, a final report project that is done in group although group working is very controversial and always debatable (Habeswa et el 1992, Martin Kent, David D Gilbertson, Chris O Hunt, 1997).

\section{Conclusion}

A review is needed in weighing each indicator generated from the fieldstudy. Weighing can be seen from the similarity in the mechanism and the product. Generally, the the conducted assessment is in the form of product and process. The four universities can formulate together the same products beside the final report; whether they needs an article, a paper, a leaflet, etc. If these products are required, the organizers, in this case the university, can give an appropriate weighing for the quantity of needed product(s).

A review of the supervisors who assess is also needed. Each of the fieldstudy is conducted by two clases which the number of participants are various among 90-100. It needs 4-6 supervisors. The supervisors have a task to assess all of the processes and the generated products in the activities of fieldstudy. Each supervisor will assess 15-20 participants from the beginning to the end of fieldstudy. The supervisor can use the phenomenon approach. This approach can be conducted to synchronize the concept of fieldstudy implementation between students and their supervisor so that the purpose of fieldstudy can be obtained (Alison Stokes, Kristy Magnier, Ruth Weaver, 2011 hlm 138)

These reviews are needed because as the institutions that graduate teacher candidates, the 
four universities should have the similarities in the process and the products required by the stakeholders. The big difference in the process and the product can provide a differenceoutcome. A curriculum reconstruction can be used as the initial step to determine procedure, material of the study, process and product and assessment that fieldstudy has an appropriate assessment.

\section{Reference}

Alison Stokes, Kristy Magnier, Ruth Weaver, (2011), What is Use fieldwork? Conceptions of Student and Staff in Geography and Geology, Journal Geography and Higher Education Vol 35 No 1 Februari 2011

Ciara O'Farrell,dr, Enhancing Student Learning Through Assessment A Toolkit Approach, Dublin Institute Technologi

Colin Marsh, (2008). Studies of Society and Enviroment Exploring the Teaching Possibilities, Person Prentice Hall, Australia.

Daniella Tilbury, Micheal Williams. (1997), Taching and Learning Geography, Routledge, London and NewYork

David Lambert Michael J Reiss, (2014), The Place Fieldwork in Geography and Science Qualifications, Leading Education and Social Research, Institute Educations, Univercity of London

Gold. J. R., Jenkins, A., Lee, R.. Monk. J.• Riley. J., Shepherd. I. D.H. \& Unwin. D. J. ( 1991) Teaching Geography in Higher Education (Oxford: Blackwell).

Higgitt, M. (1996) Addressing The New Agenda for Fieldwork in Higher Education, Journal of Geography in Higher Education, 20(3), pp. 391398.

HMI (Her Majesty's Inspectorate) (1992) $A$ Survey of Geography Fieldwork in Degree Courses. Sler 1990-Summer 1991: a Report by HM/. Report 9/92/NS (Sranmore: Her Majestyv Inspectorate. Department of Education and Science).
IAAM (The Incorporated Association of Asisstant Masters), (2013). The Teaching of Geography in Secondary Scholls, Cambridge University Press.

Ian Fuller, Sally Edmondson, Derk France, David Higgit \& Ilkka Ratinen (2006). International Perspectives on the Effectiveness of Geography Fieldwork for Learning, Taylor \& Francis Journal of Geography in Higher Education, Vol. 30, No. J, 89-101. March 2006

James Walker. (1980). Performance Management. London: Institute of Personel and Development

Kunandar. (2014). Penilaian Autentik (Penilian Hasil Belajar Peserta Didik Berdasarkan Kurikulum 2013), Rajagrafindo Persada, Bandung

Kwok Chan Lai and Chi Chung Lam (2013). School-Baseed Assessment ofFiledwork in Hongkong Dilemas and Chalanges,Geography Vol 9 Part 1 Spring 2013

Macquire University. (2008). Assessment Toolkit Resources, Creating Authentic Assessment, Learning and Teaaching Center, Macquire University Sydney

March Behrendt, Theresia Franklin, (2014) A Review of Research on Schooll Filed trips and Their Value in Education, International Journal Of Enviromental \& Scinence Education (2014), 9, 235-245

Martin Kent, David D Gilbertson, Chris O Hunt (1997), Fieldwork in Geography Teaching : a Critical Review of Literature and Approaches, Carfax Published Ltd

Max Hope, (2009) The Importance of Direct Experience : A Philosophical Defence of Filedwork in Human Geografphy, Journal Of Geography in Higher Education Vol. 33, No 2, 169-182, May 2009, Rouledge

Mulyantari. (2005). "Kuliah Kerja Lapangan (KKL) I Geografi Sebagai Salah Satu Metode Pembelajaran Kontekstual dan Pengaruhnya Terhadap Prestasi Belajar 
Mahasiswa Pendidikan Geografi". (skripsi). Jurusan Geografi. FIS. UNES. Semarang

Neil Labo. (2007). An Assignment For The 'Issues of Concern in Geographic Education' Module. Student Journals and a Geography Field trip in Costarica

Rod Gerber, Goh Kim Chuan (2000). Fieldwork in Geography: Reflection, Perspektives and Actions, Springer Scince Busines Media B.V

SheirAzim, Muhamad Khan. (2012). Authentic Assessment: An Instructional Tool To Enhance Student Learning, Academic Research International. SAVAP Journal

Sriadi Setyawati, Dyah Respati Suryo Sumunar. (2010). Panduan Pelaksanaan Praktik Kuliah
Lapangan (PKL) Geografi Terpadu Yogyakarta, Jurusan Pendidikan Geografi Fakultas Ilmu Sosial UNY

Stephen Pui-ming Yeuing (2009), Assessment Geographycal Fieldwork in Public Examination : Ratinonale, Problem and Prospects, Geographical Education, Vol 22, 2009

UNJ (2012) Pengembangan Kurikulum Program Studi Pendidikan Geografi Fakultas IImu Sosial, Program ini di Danai Oleh Islamic Devolepment Bank

UPI. (2015). Pedoman Penuliasan Karya IImiah UPI Tahun Akademik 2015, Bandung, Universitas Pendidikan Indonesia. 